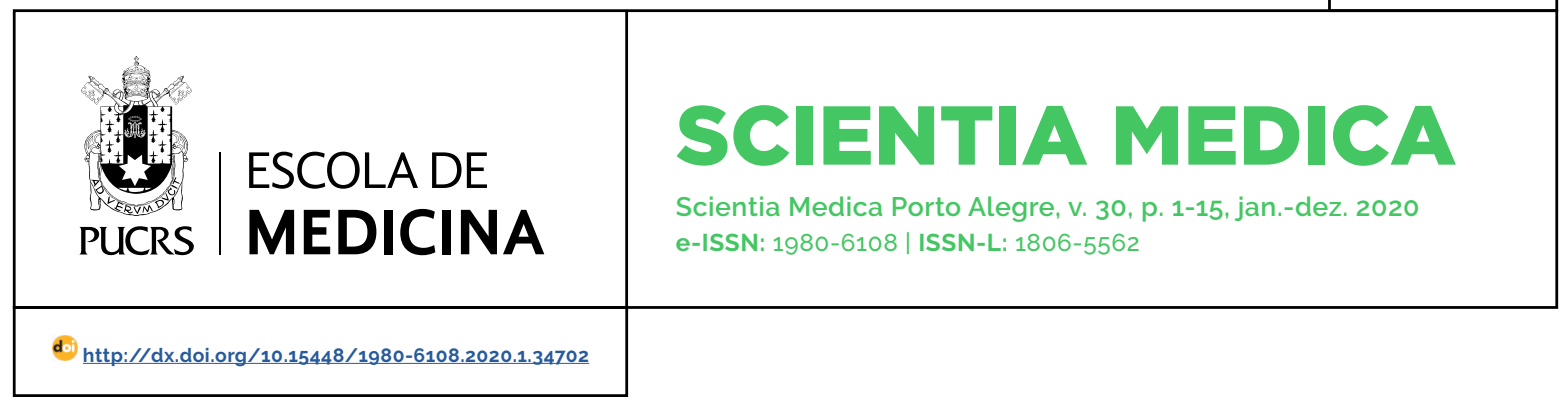

ORIGINAL ARTICLE

\title{
Antioxidant potential of Carica papaya Linn (Caricaceae) leaf extract in mice with cyclophosphamide induced oxidative stress
}

\author{
Potencial antioxidante do extrato de folhas de Carica papaya Linn (Caricaceae) em \\ camundongos com estresse oxidativo induzido por ciclofosfamida
}

\author{
Tatiane Cordeiro Luiz \\ orcid.org/0000-0001-8665-0511 \\ tatianeredhot@hotmail.com
}

\section{Ana Paula Simões da Cunha $^{1}$}

orcid.org/0000-0002-3545-1034 anasimoescunha@hotmail.com

Danilo Henrique Aguiar ${ }^{1}$ orcid.org/0000-0003-0385-6093 dha.danilo@gmail.com

\section{Marina Mariko Sugui ${ }^{1}$ \\ orcid.org/0000-0002-3784-2821 masugui@hotmail.com}

\section{Rogério de Campos Bicudo²}

orcid.org/0000-0001-6987-5751 rogerio.bicudo@embrapa.br

\section{Adilson Paulo Sinhorin ${ }^{1}$ orcid.org/0000-0002-4133-8994 sinhorin.adilson@gmail.com}

\section{Valéria Dornelles Gindri Sinhorin ${ }^{1}$}

orcid.org/0000-0002-5070-0043 valeriadgindri@gmail.com

Recebido em: 24 jul. 2019. Aprovado em: 26 mar. 2020 Publicado em: 19 jun. 2020.

\section{(c) (1)}

Artigo está licenciado sob forma de uma licença Creative Commons Atribuição 4.0 Internacional.

\section{ABSTRACT}

AIMS: This study aimed to investigate the effects of crude extract of Carica papaya leaves on oxidative stress in mice induced by cyclophosphamide, as well as phytochemical profile characterization of this extract.

METHODS: The male Swiss mice received 15 days of treatment with the extract (500 mg kg-1 , via gavage) and intraperitoneal injection of cyclophosphamide (75 $\mathrm{mg} \mathrm{kg}^{-1}$ ) or saline $(0.9 \%)$ on the $15^{\text {th }}$ day. After $24 \mathrm{~h}$ the last treatment, the animals were anesthetized for blood withdrawal, sacrificed and removal of the organs for analyses (liver, kidney and heart). In the biochemical tests were determined: hematological parameters in blood, aminotransferases, alkaline phosphatase, glucose and total cholesterol dosages in plasma, enzymatic and non-enzymatic antioxidants and lipid damage marker were evaluated in different tissues, besides genotoxic and histopathological analyzes.

RESULTS: In the extract of Carica papaya leaves, the flavonoids quercetin-3 $\beta-D-$ -glucoside and rutin were identified, besides present positive results for alkaloids, saponins and tannins. This extract increased the activity of glutathione-S-transferase and catalase enzymes in the liver and reduced the levels of reduced glutathione in the kidneys and hematocrit levels, red cell count, and hemoglobin. It promoted the decrease of the reactive species of thiobarbituric acid (TBARS) in the kidneys and the activity of enzyme aspartate aminotransferase in the plasma and was antimutagenic in the micronucleus test.

CONCLUSIONS: The study showed that extract of Carica papaya was beneficial against oxidative events and prevented DNA damage. The extract also showed hepatotoxicity, therefore prolonged infusion of papaya leaves is not advisable.

Keywords: antimutagenicity; antioxidant defense; ethnobotany; secondary metabolites; erythropoiesis.

\section{RESUMO}

OBJETIVOS: O objetivo deste estudo foi investigar os efeitos do extrato bruto de folhas de Carica papaya sobre o estresse oxidativo em camundongos induzidos pela ciclofosfamida, bem como a caracterização do perfil fitoquímico deste extrato. MÉTODOS: Os camundongos Swiss machos receberam 15 dias de tratamento com o extrato (500 $\mathrm{mg} \mathrm{kg}^{-1}$, via gavagem) e injeção intraperitoneal de ciclofosfamida ( $75 \mathrm{mg} \mathrm{kg}^{-1}$ ) ou salina $(0,9 \%)$ no $15^{\circ}$ dia. Após $24 \mathrm{~h}$ do último tratamento, os animais foram anestesiados para retirada do sangue, sacrificados e retirada dos órgãos para análises (fígado, rim e coração). Nos testes bioquímicos foram determinados: parâmetros hematológicos em sangue, aminotransferases, fosfatase alcalina, dosagens de glicose e colesterol total no plasma, antioxidantes enzimáticos e não enzimáticos e marcador de dano lipídico foram avaliados em diferentes tecidos, além de análises genotóxicas e histopatológicas.

RESULTADOS: No extrato de folhas de Carica papaya foram identificados os flavonoides quercetina-3 $\beta$-D-glicosídeo e rutina, além de resultados positivos para 
alcaloides, saponinas e taninos. Este extrato aumentou a atividade das enzimas glutationa-S-transferase e catalase no fígado e diminuiu os niveis de glutationa reduzida nos rins, a concentração do hematócrito, a contagem dos glóbulos vermelhos e a hemoglobina. Promoveu a diminuição das espécies reativas de ácido tiobarbitúrico (TBARS) nos rins, a atividade da enzima aspartato aminotransferase no plasma e foi antimutagênico no teste do micronúcleo.

CONCLUSÕES: O estudo mostrou que o extrato de Carica papaya foi benéfico contra eventos oxidativos e preveniu danos no DNA. O extrato também mostrou hepatotoxicidade, portanto, a infusão prolongada de folhas de mamão não é aconselhável.

Descritores: antimutagenicidade; defesa antioxidante; etnobotânica; metabólitos secundários; eritropoiese.

ABBREVIATIONS: ALP, alkaline phosphatase; ALT, alanine aminotransferase; AST, aspartate aminotransferase; CAT, catalase; CE, crude extract; CP, Cyclophosphamide; DPPH', 1,1-diphenyl-2-picryl hydrazil; GST, glutathione-S-transferase; Hb, hemoglobin; HCT, Hematocrit; LC-MS/MS, liquid chromatography coupled to mass spectrometry; MDA, malondialdehyde; $\mathrm{mg} \mathrm{EQ} \mathrm{g}^{-1}$, milligrams of quercetin equivalent per gram of extract; PCE, polychromatic erythrocytes; PCEMN, micronucleated polychromatic erythrocytes; RBC, red cell count; SOD, superoxide dismutase; TBARS, thiobarbituric acid; Tris, trisaminomethane; WBC, white cell count.

\section{INTRODUCTION}

Free radicals are molecules or molecular fragments containing one or more unpaired electrons, a condition that confers high reactivity and may present considerable interference in cellular integrity [1]. The adverse effects of free radicals occur when there is an overproduction of reactive species and a deficiency of antioxidant enzymes and non-enzymatic antioxidants (reduced glutathione, ascorbic acid, tocopherols, carotenoids, vitamins A and E) [2].

The organism has an antioxidant defense system, enabling the evaluation of oxidative stress by means of analysis of some antioxidant enzyme activities such as superoxide dismutase (SOD), catalase (CAT), glutathione peroxidase, glutathione-S-transferase (GST) and others such as reduced such as reduced gluthatione (GSH) levels as even though it is a non-enzymatic antioxidant agent, GSH can act as a substrate in the reactions catalyzed by enzymes, for example GST, or can act directly in free radical scanning [3].An additional parameter useful in evaluating oxidative stress is the lipid peroxidation generated in the cellular membranes. This triggers several actions harmful to the cell, which can result in its death. As the free radical has a very short halflife, it is only possible to be measured by markers such as malondialdehyde through TBARS analysis (thiobarbituric acid reactive substances) [4].

Cyclophosphamide (CP) is a widely used drug for the treatment of chronic diseases, autoimmune diseases and cancer [5]. The antineoplastic activity of $\mathrm{CP}$ is due to phosphoramide mustard, which promotes the alkylation of DNA, in addition to the other metabolite, acrolein, which interferes with the antioxidant system producing reactive species, superoxide radical and hydrogen peroxide, leading to toxicity of various organs [6].

The Carica papaya Linn, known as mamoeiro (in Brazil) is a tree present in tropical and subtropical regions of the world, with its fruit known as papaya. The fruit stands out as having a pleasant taste and aroma and high nutritional value, being rich in sugars, calcium, carotenoids and vitamin C [7].

The fruits, leaves, flowers, roots, seeds and even latex are all widely used in traditional medicine to treat a variety of diseases. In particular, the leaves are used in healing, in the treatment of dengue, jaundice and malaria [8]. Some studies have investigated these medicinal properties of the leaves, for example the methanolic extract promoted inhibition of sickle hemoglobin formation and hemolysis in vitro tests [9] and antioxidant and cytoprotective action of the hydrometanolic extract in human liver cell lines oxidatively stressed with tert-butyl peroxide [10]. The ethanolic extract presented analgesic action compared to the aspirin action in an experimental model with mice [11]; antibacterial and antithrombocytopenic activity in Wistar rats using aqueous extract and lastly antiproliferative and antimetastatic activity of dry leaf extract on prostate cancer cell lines was observed [12].

The objective of the present study was to investigate the effects of raw aqueous extract of C. papaya leaves on biochemical, hematological and mutagenic parameters in mice induced by oxidative stress induced by cyclophosphamide, an experimental model adopted unpublished in the literature, besides the phytochemical characterization of the extract. 


\section{MATERIAL AND METHODS}

\section{Chemical products}

$\mathrm{CP}$ from Baxter, amentoflavone, apigenin, canferol, luteolin, quercetin, quercetin-3ß-Dglucoside, rutin, taxifoline, aluminum chloride, 1,1-diphenyl-2-picryl hydrazil (DPPH'), ascorbic acid, Triton X-100, hydrogen peroxide, reduced glutathione (GSH), 2-thiobarbituric acid, 5.5'-dithiobis (2-nitrobenzoic acid), Bradford's reagent, trichloroacetic acid, potassium phosphate monobasic, potassium phosphate dibasic, sodium phosphate, Ethylenediamine tetraacetic acid, trisaminomethane (Tris) and bovine serum albumin were all purchased from Sigma-Aldrich (St. Louis, USA). The solvents used for the tests were all from Merck. Glucose, cholesterol, alanine aminotransferase (ALT), aspartate aminotransferase (AST) and alkaline phosphatase (ALP) dosages used were from kits purchased from Labtest ${ }^{\circledR}$, Diagnóstico S.A, Minas Gerais, Brazil.

\section{Collection and botanical identification}

The leaves of $C$. papaya were collected in the city of Sinop, Mato Grosso, Brazil, geographical coordinates S 1153'53.016" W 5530'18.828". Voucher specimens were deposited in the Herbarium Centro Norte Matogrossense, Federal University of Mato Grosso under registration number 7012 and identified by Professor Milton Omar Côrdova Neyra.

\section{Preparation of Carica papaya Linn extract}

For the preparation of the extract, the leaves of $C$. papaya were collected and cleaned with distilled water and exposed to the fan-forced oven drying process at an average temperature of 40 ${ }^{\circ} \mathrm{C}$ for seven days. After drying, the leaves were crushed, yielding a weight of $220 \mathrm{~g}$. The crushed leaves were infused with distilled water ( $4.5 \mathrm{~L}$ ) under a stable temperature of $70^{\circ} \mathrm{C}$ for 1 hour in a water bath. After this time, the material was filtered and rotated with vacuum pump under reduced pressure and water bath at $60^{\circ} \mathrm{C}$. Subsequently, the samples were frozen and lyophilized to obtain the final crude extract (CE) of $68.47 \mathrm{~g}$.

The aqueous extract was produced to resemble that which is used by the general population, in which it is commonly used to make tea or as an infusion. The selected dose was $500 \mathrm{mg} \mathrm{kg}^{-1}$,in accordance with [13].

\section{Determination of flavonoids and DPPH' test}

The determination of the amount of total flavonoids was performed using quercetin as a standard curve in a reaction with aluminum chloride, in accordance with [14]. The result was expressed in milligrams of quercetin equivalent per gram of extract ( $\mathrm{mg} \mathrm{EQ} \mathrm{g}^{-1}$ ).

The antioxidant potential of the vegetable extract was evaluated based on the methodology of [15]. From the consumption of the DPPH' free radical (2,2-diphenyl-1-picrylhydrazine) in the samples, the absorbance of the solutions read at wavelength $515 \mathrm{~nm}$ using rutin and ascorbic acid as standards was measured.

\section{Phytochemical screening}

The presence of other secondary metabolites in the extract was evaluated through qualitative tests; the colorimetric tests were used to verify the presence of alkaloids, coumarins, steroids, saponins, polysaccharides, purines and tannins following the methodology of [16].

Phytochemical identification of C. papaya leaves by liquid chromatography coupled to mass spectrometry

The analytical standards for amentoflavone, apigenin, canferol, luteolin, quercetin, quercetin$3 \beta$-d-glucoside, rutin and taxifoline were used to identify flavonoids present in the leaves of $C$. papaya. The extract was subjected to liquid chromatography coupled to mass spectrometry (LC-MS/MS) using a 1290 Infinity UHPLC system (Agilent Technologies) coupled to a 6460 Triple Quad LC/MS (Agilent Technologies) in which a system pumps with 20 $\mu \mathrm{L}$ of sample injected via the self-injection system.

Separation of the compounds occurred on a C-18 column (Zorbax Eclipse AAA of $4.6 \times 150$ $\mathrm{nm}$ diameter, $3.5 \mu \mathrm{m}$ particle size). The sample elution method used a flow rate of $0.5 \mathrm{~mL} \mathrm{~min}^{-1}$ and an elution gradient composed of Solvent $A$ (water : formic acid; 99.9: 0.1\% (v/v)) and Solvent B 
(acetonitrile: formic acid; 99.9: 0.1\% (v/v)), having the following characteristics: 0-30 min: 95-5\% B, 30-32 min: 0-100\% B, 32-33 min: 95-5\% B. The samples were detected by mass spectrometry using electrospray ionization ( $\mathrm{m} / \mathrm{z}-1)$. The identification of flavonoids occurred in the mode of acquisition by negative ionizationaccording to [17], source temperature 300 ${ }^{\circ} \mathrm{C}$, and desolvation temperature $250{ }^{\circ} \mathrm{C}$.

\section{Animals and experimental design}

This research was approved by the Animal Use Ethics Committed under protocol number 28108.722412 / 2017-58. Male Swiss mice, with a mean weight of 30-40 g, were used. Throughout the experiment's entirety, the animals were kept under controlled conditions of temperature $(22 \pm 2$ ${ }^{\circ} \mathrm{C}$ ), relative humidity ( $55 \pm 10 \%$ ), light cycle (12 hours light/dark), commercial diet and filtered water kept in boxes of polyethylene and stainless-steel grid. The acclimatization period was two weeks. The animals received oral treatments (water with vehicle or extract, by gavage $(0.3 \mathrm{~mL})$ for 15 days and an intraperitoneal injection of CP or saline on the $15^{\text {th }}$ day. The following are the groups and their treatments (Figure 1). CP at a concentration of 75 $\mathrm{mg} \mathrm{kg}^{-1}$ following the protocol of [18].

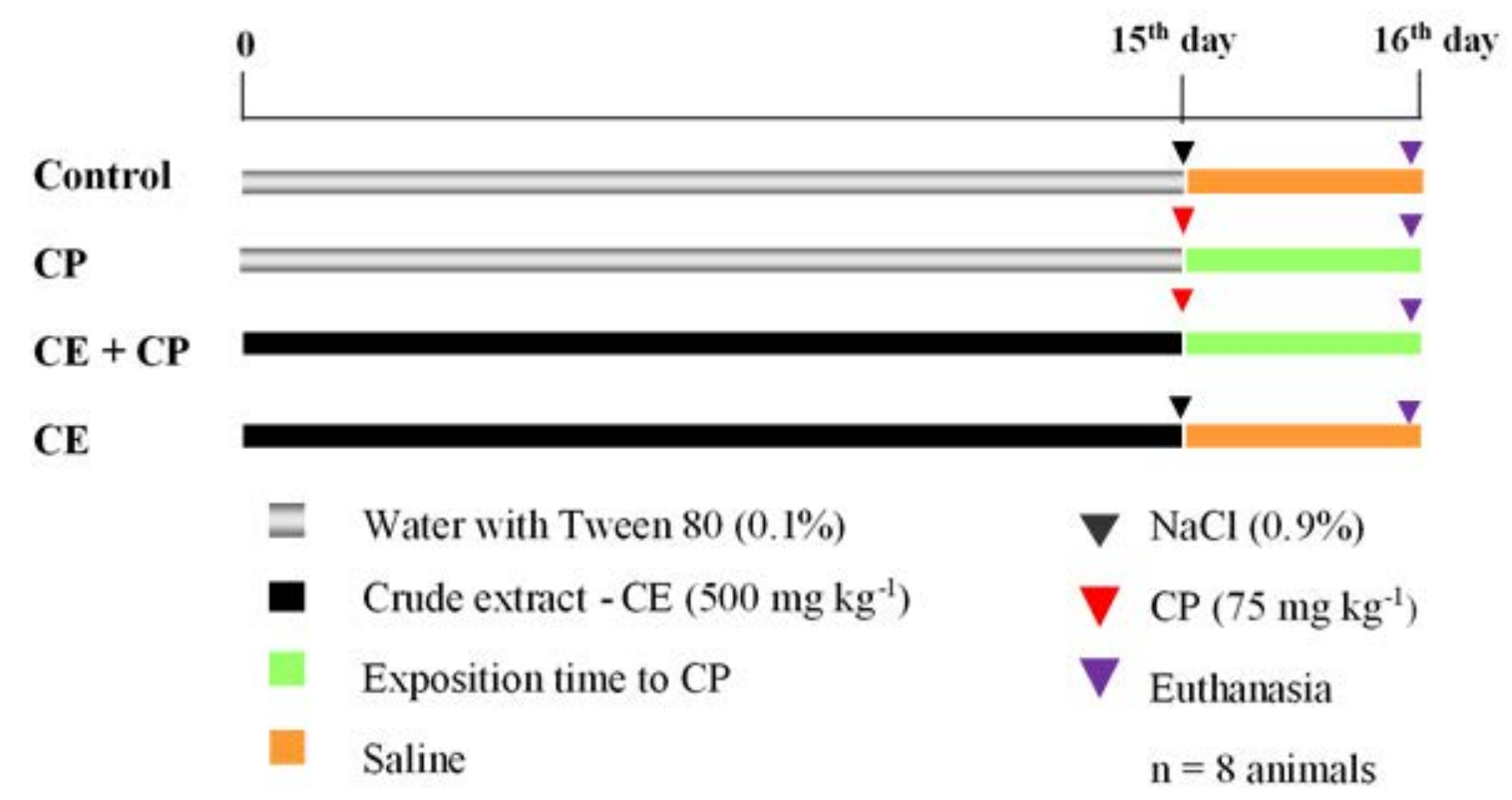

Figure 1 - Experimental design for the evaluation of antioxidant and antimutagenic effects of the CE of C. papaya. CE: Crude extract; CP: cyclophosphamide

\section{Biochemical and hematological analyzes}

Twenty-four hours after the last treatment dose and 8 hours of fasting, the animals were anesthetized intraperitoneally with ketamine 50 $\mathrm{mg} \mathrm{kg}^{-1}$, xylaxine $20 \mathrm{mg} \mathrm{kg}^{-1}$ and acepromazine 20 $\mathrm{mg} \mathrm{kg}^{-1}$. Blood was withdrawn via cardiac puncture

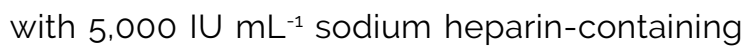
syringes and the animals were subsequently sacrificed for liver, kidney and heart samples, which were frozen at $-80{ }^{\circ} \mathrm{C}$.

Biochemical analyzes were performed on superoxide dismutase (SOD) based on [19], the result being expressed as UI SOD mg protein ${ }^{-1}$. Catalase activity (CAT) was measured according to [20] and the results expressed in $\mu \mathrm{mol} \mathrm{min}^{-1} \mathrm{mg}$ protein $^{-1}$. GST analysis followed the methodology [21], with the GST activity expressed in $\mu \mathrm{mol}$ GSDNB min $^{-1}$ mg protein ${ }^{-1}$. Reduced glutathione (GSH) was quantified according to [22], with thiolate anion formation evaluated and compared to a standard GSH curve. The result was expressed in $\mu \mathrm{mol}$ GSH mg protein ${ }^{-1}$. The thiobarbituric acid reactive substances (TBARS) followed the method 
described by [23].The results were compared with a calibration curve of increasing concentration of $0.75,1.5,3.0,6.0,12.0 \mathrm{mM}$ MDA (malondialdehyde) and the amount of lipid peroxidation was expressed in nmol MDA mg protein ${ }^{-1}$. Analysis of the protein content of the samples of all tissues is necessary to obtain the results of the tests in $\mathrm{mg} \mathrm{protein}^{-1}$, followed by the method of [24].

Glucose, cholesterol, aspartate aminotransferase (AST), alanine aminotransaminase (ALT) and alkaline phosphatase (ALP) assays were all assayed using commercial (Labtest ${ }^{\circledR}$ ) kits. Hematocrit (HCT), white cell count (WBC), red cell count (RBC), hemoglobin $(\mathrm{Hb})$ and platelets were determined using the biochemical analyzer (XT-1800o Sysmex, Roche, Hitachi Ltd, Tokyo, Japan).

\section{Micronucleus test}

The micronucleus test was performed in accordance with the methodology of [25] where 1000 cells per slide (two slides) and 2000 polychromatic erythrocytes (PCE) per animal were analyzed. The observation was performed under blind test using a light microscope with 1000 times magnification. The objective of this test is to observe the frequency of micronucleated polychromatic erythrocytes (PCEMN) indicating DNA damage.

A formula was used to verify the percent of harm reduction as the mean frequency decrease of micronucleated cells according to [26]and [27] using the formula:

(\%) reduction $=($ frequency of MNPCEs in A - frequency of MNPCEs in B) $\times 100$ (frequency of MNPCEs in A - frequency of MNPCEs in C)

Where A corresponds to the CP group (positive control); $B$ to the analysis group (group receiving the extract and $\mathrm{CP}$ ) and $\mathrm{C}$ to the negative control group.

\section{Histology of the liver}

The livers of the mice were removed at the end of the experiment and fixed in 10\% buffered formalin. Subsequently, they were cut transversely and dehydrated with ethanol and embedded in paraffin. Paraffin sections of approximately $4 \mu \mathrm{m}$ were assembled and stained with Hematoxylin and Eosin. The evaluation criteria for histological analysis were the observation of the sinusoids and central vein if there were dilation, infiltrations in the hepatic tissue by inflammatory cells and vacuolization.

\section{STATISTICAL ANALYSIS}

In order to compare the differences in the biochemical variables between pretreatment (water with vehicle or extract) and treatment (CP or saline), statistical analyses were performed using one-way or two-way analysis of variance (ANOVA) followed by the Tukey's test. Bartlett's test was performed to compare the homogeneity of variances among the groups. Data were expressed as mean \pm standard deviation. For the micronucleus frequency test, the chi-square test was used according to [28].

\section{RESULTS}

Flavonoid content and antioxidant activity in vitro

The CE extract presented low antioxidant activity in vitro when compared to ascorbic acid and rutin standards, not being able to reach $50 \%$ elimination of the $\mathrm{DPPH}^{\cdot}$ radical. On the total flavonoids, the value of $21.7 \mathrm{mg} \mathrm{EQ} \mathrm{g}^{-1}$ was obtained in the CE (data not shown).

\section{Presence of compounds by phytochemical screening}

In the phytochemical screening of CE, the tests showed positive results only for the presence of alkaloids, saponins and tannins (data not shown).

Flavonoids identified in liquid chromatography coupled to mass spectrometry (LC-MS/MS)

In the LC-MS/MS analysis of the CE, flavonoids rutin and quercetin-3 $\beta$-D-glycoside were identified (Figure 2). All information on the retention time, molecular ion and fragmentation of the compounds are in Table 1. 
<smiles>O=c1c(OC2OC3OC(C2O)C(O)C(O)C3O)c(-c2ccc(O)c(O)c2)oc2cc(O)cc(O)c12</smiles>

Compound 1<smiles>O=c1c(OC2OC(CO)C(O)C(O)C2O)c(-c2ccc(O)c(O)c2)oc2cc(O)cc(O)c12</smiles>

Compound 2

Figure $\mathbf{2}$ - Structure of the flavonoids found in the crude extract.

TABLE 1 - Characterization by LC-MS/MS of the compounds identified in CE of C. papaya.

\begin{tabular}{ccccccc}
\hline Compound & $\mathrm{RT}(\mathrm{min})$ & $\begin{array}{c}\mathrm{MW} \\
\left(\mathrm{g} \mathrm{mol}^{-1}\right)\end{array}$ & {$[\mathrm{M}-\mathrm{H}]$} & $\mathrm{MS}^{2}$ & $\begin{array}{c}\text { Compound } \\
\text { identified }\end{array}$ & $\begin{array}{c}\text { Molecular } \\
\text { formula }\end{array}$ \\
\hline 1 & 10 & 610.52 & 609.52 & 300.20 & Rutin & $\mathrm{C}_{27} \mathrm{H}_{30} \mathrm{O}_{16}$ \\
2 & 10.3 & 464.38 & 463.38 & 300.00 & $\begin{array}{l}\text { Quercetin-3- } \beta \\
\text {-D-glycoside }\end{array}$ & $\mathrm{C}_{21} \mathrm{H}_{20} \mathrm{O}_{12}$ \\
\hline
\end{tabular}

CE, crude extract; LC-MS/MS, liquid chromatography mass spectrometry; [M-H], Less Hydrogen Molecule; MS; fragment identified; MW. Molecular weight; RT, retention time in minutes

\section{Biomarkers of oxidative stress}

The activity of the SOD and GST enzymes of the hepatic tissue was evaluated, according to Figure $\mathbf{3}$ ( $A$ and $B$, respectively). There was a significant reduction in SOD activity $(p<0.05)$ in the $\mathrm{CP}$ group (27\%) and in the group receiving $\mathrm{CE}$ plus CP (29\%) compared to the control group. The CE could not prevent the decrease of SOD by CP. GST activity showed a significant increase ( $p$ $<0.05$ ) in the CP group of $37 \%$, and in the groups that received CE plus $\mathrm{CP}(41 \%)$ and CE alone (36\%), compared to control.
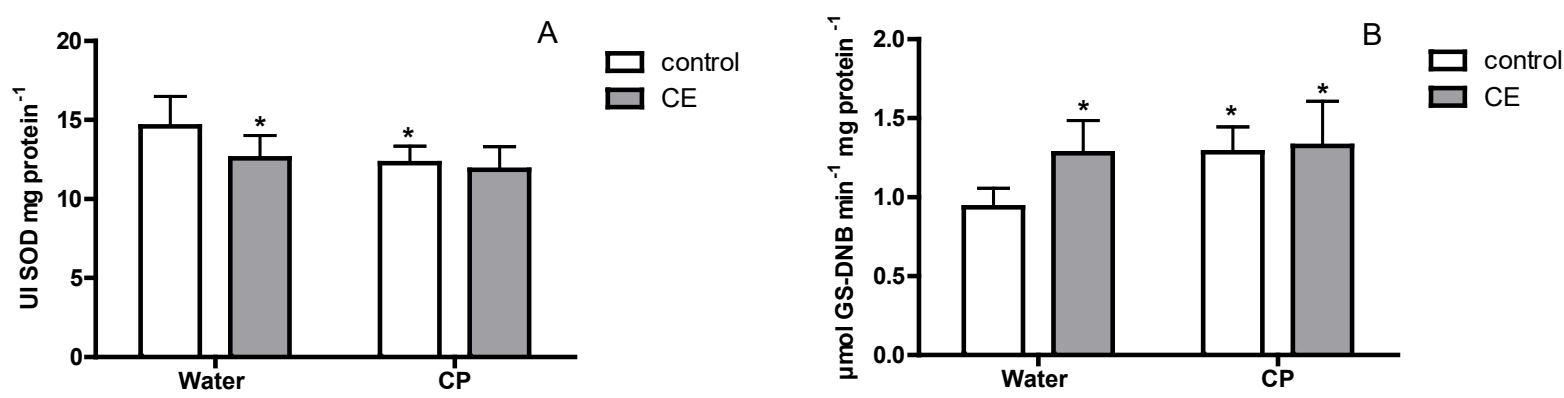

Figure $\mathbf{3}$ (A, B) - Effect of CE pre-treatment ( $500 \mathrm{mg} \mathrm{kg}^{-1}$ ) on CP-induced oxidative stress ( $75 \mathrm{mg} \mathrm{kg}^{-1}$ ) for the evaluation of enzymatic biomarkers SOD and GST in hepatic tissue $(n=8)$. Anova followed by Tukey test. * $p<0.05$ compared to control. CE: crude extract; CP: cyclophosphamide; GST: glutathione-S-transferase; SOD: superoxide dismutase. 
Table 2 shows CAT activity in the hepatic, renal and cardiac tissues. In the hepatic tissue a significant reduction of the CAT $(p<0.05)$ in the CP group was observed, a reduction of $24 \%$ in comparison to the control. However, CE significantly restarted CAT activity $(p<0.05)$, the action of CP. The other tissues did not present significant differences.

TABLE 2 - Effect of CE pre-treatment $(500 \mathrm{mg}$ $\mathrm{kg}^{-1}$ ) on CP-induced oxidative stress (75 $\mathrm{mg} \mathrm{kg}^{-1}$ ) for evaluation of catalase activity in hepatic, renal and cardiac tissues.

\section{Catalase $\left(\mu \mathrm{mol} \mathrm{min}^{-1} \mathrm{mg}\right.$ protein $\left.{ }^{-1}\right)$}

\begin{tabular}{cccc}
\hline Treatments & Liver & Kidney & Heart \\
Control & $31.81 \pm 4.01$ & $44.83 \pm 10.76$ & $8.06 \pm 1.60$ \\
CP & $24.30 \pm 3.66$ & $44.67 \pm 7.23$ & $6.73 \pm 1.49$ \\
CE + CP & $31.89 \pm 6.73^{* *}$ & $50.15 \pm 9.70$ & $7.41 \pm 1.50$ \\
CE & $30.44 \pm 3.60$ & $48.78 \pm 7.76$ & $9.92 \pm 2.14$ \\
\hline
\end{tabular}

${ }^{*} \mathrm{p}<0.05$ compared to control. ${ }^{* *} \mathrm{p}<0.05$ compared to the CP group. CE, crude extract; CP cyclophosphamide; $(n=8)$.

The GSH levels (Table 3) saw a significant decrease in GSH content ( $p<0.05)$ in liver $(32 \%)$, kidney (35\%) and heart (41\%) in the CP group. CE significantly increased GSH ( $p<0.05$ ), preventing $\mathrm{CP}$ action in renal tissue, and an increase of $72 \%$ when compared with CP group.

TABLE 3 - Effect of pre-treatment with CE (500 $\mathrm{mg} \mathrm{kg}^{-1}$ ) on CP-induced oxidative stress $(75 \mathrm{mg}$ $\mathrm{kg}^{-1}$ ) for evaluation of GSH in hepatic, renal and cardiac tissues.

\begin{tabular}{cccc}
\hline \multicolumn{4}{c}{$\begin{array}{c}\text { Reduced glutathione - GSH } \\
\left(\mu \mathrm{mol} \text { GSH mg protein }{ }^{-1}\right)\end{array}$} \\
\hline Treatments & Liver & Kidney & Heart \\
Control & $10.83 \pm 1.62$ & $5.47 \pm 0.88$ & $36.44 \pm 7.00$ \\
CP & $7.43 \pm 0.87$ & $3.58 \pm 0.83^{\circ}$ & $21.80 \pm 5.46$ \\
CE + CP & $9.63 \pm 2.89$ & $6.17 \pm 1.54$ & $25.32 \pm 4.13$ \\
CE & $9.82 \pm 1.68$ & $6.22 \pm 1.52$ & $34.45 \pm 8.07$ \\
\hline
\end{tabular}

* $p<0.05$ compared to control. ** $p<0.05$ compared to the CP group. CE, crude extract; CP, cyclophosphamide; $(n=8)$.
To verify lipid peroxidation, the levels of malondialdehyde (MDA) were evaluated by means of the TBARS test in all tissues, according to Table 4. There was a significant increase of TBARS ( $p$ $<0.05)$ in hepatic (124\%) and renal (32\%) tissues in the CP group compared to control. While CE significantly decreased TBARS levels $(p<0.05)$ even after receiving $C P$, a $39 \%$ decrease in hepatic tissue and $46 \%$ decrease in renal tissue when compared to the CP group. The CE-only group induced a significant increase of $50 \%$ of TBARS $(p<0.05)$ in the liver, comparing with control. No significant differences were observed in cardiac tissue.

TABLE 4 - Effect of CE pre-treatment $(500 \mathrm{mg}$ $\mathrm{kg}^{-1}$ ) on CP-induced oxidative stress $\left(75 \mathrm{mg} \mathrm{kg}^{-1}\right.$ ) to assess the biomarker of lipid damage in hepatic, renal and cardiac tissues.

Thiobarbituric acid reactive species - TBARS (nmol MDA mg protein ${ }^{-1}$ )

\begin{tabular}{cccc}
\hline Treatments & Liver & Kidney & Heart \\
Control & $0.37 \pm 0.06$ & $2.37 \pm 0.50$ & $5.41 \pm 1.00$ \\
CP & $0.84 \pm 0.15^{*}$ & $3.13 \pm 0.61^{*}$ & $4.50 \pm 1.14$ \\
CE + CP & $0.51 \pm 0.11^{* *}$ & $1.71 \pm 0.29^{* *}$ & $5.34 \pm 0.57$ \\
CE & $0.56 \pm 0.12^{*}$ & $2.29 \pm 0.24$ & $5.93 \pm 1.55$ \\
\hline
\end{tabular}

" $p<0.05$ compared to control. " $p<0.05$ compared to the CP group. CE, crude extract; CP, cyclophosphamide; MDA, Malondialdehyde; $(n=8)$.

\section{Blood parameters}

Biochemical parameters of the plasma of the treated animals were evaluated (Table 5). A significant increase $(p<0.05)$ of AST and ALP enzymes was observed, of $26 \%$ and $64 \%$ in the CP group compared to the control, respectively. Animals pretreated with CE had a significant decrease $(p<0.05)$ in AST. On the other hand, an increase in ALP was verified in CE plus CP when compared to control and also it was observed that CE alone also increased significantly $(\mathrm{p}<$ 0.05 ) the ALT and ALP enzymes, in $89 \%$ and $74 \%$, respectively, when compared with control. No significant differences were observed in glucose and cholesterol among the groups tested. 
TABLE 5 - Effect of CE pre-treatment $\left(500 \mathrm{mg} \mathrm{kg}^{-1}\right.$ ) on CP-induced oxidative stress (75 $\mathrm{mg} \mathrm{kg}^{-1}$ ) for the evaluation of plasma biochemical parameters (AST, ALT, ALP, glucose and cholesterol).

\begin{tabular}{|c|c|c|c|c|c|}
\hline Treatments & $\begin{array}{l}\text { AST } \\
\left(U L^{-1}\right)\end{array}$ & $\begin{array}{l}\text { ALT } \\
\left(U L^{-1}\right)\end{array}$ & $\begin{array}{l}\text { ALP } \\
\left(U L^{-1}\right)\end{array}$ & $\begin{array}{l}\text { Glucose } \\
\left(\mathrm{mg} \mathrm{dL}^{-1}\right)\end{array}$ & $\begin{array}{l}\text { Cholesterol } \\
\left(\mathrm{mg} \mathrm{dL}^{-1}\right)\end{array}$ \\
\hline Control & $103.5 \pm 20.2$ & $47.1 \pm 10.6$ & $63.7 \pm 12.3$ & $246.2 \pm 44.6$ & $69.4 \pm 11.7$ \\
\hline $\mathrm{CP}$ & $130.8 \pm 27.2^{\circ}$ & $44.0 \pm 10.3$ & $104.5 \pm 11.2$ & $271.4 \pm 36.9$ & $68.2 \pm 14.5$ \\
\hline $\mathrm{CE}+\mathrm{CP}$ & $83.7 \pm 11.9^{\prime \prime}$ & $66.1 \pm 13.8$ & $89.6 \pm 8.5^{\circ}$ & $286.8 \pm 46.4$ & $80.7 \pm 8.3$ \\
\hline CE & $94.0 \pm 16.9$ & $89.0 \pm 7.0^{\circ}$ & $111.2 \pm 11.2^{\circ}$ & $288.6 \pm 65.4$ & $76.0 \pm 13.3$ \\
\hline
\end{tabular}

${ }^{*} \mathrm{p}<0.05$ compared to control. ${ }^{* *} \mathrm{p}<0.05$ compared to the CP group. ALP, alkaline phosphatase; ALT, alanine aminotransferase; AST, aspartate aminotransferase; CE, crude extract; CP, cyclophosphamide; $(n=7)$.

When estimating HCT levels, a significant increase $(p<0.05)$ was observed in the CP group of $16 \%$, in the group that received CE plus the CP and CE group, both with a $17 \%$ increase compared to control. In WBC, a significant reduction ( $p<0.05)$ of $50 \%$ was observed in the CP group and in the group receiving $\mathrm{CE}$ plus $\mathrm{CP}$, with a reduction of $65 \%$ compared with the control group. The levels of RBC and $\mathrm{Hb}$ presented a significant increase
( $p<0.05$ ) of $20 \%$ and $21 \%$, respectively, in the CP group compared to the control group. Likewise, a significant increase in RBC was observed in the group receiving CE plus CP (19\%), and in the CE group (18\%). Hb also increased significantly $(p<0.05)$ in the CE plus CP $(22 \%)$ and CE $(19 \%)$ groups. No significant difference was observed in platelets. All data on whole blood biochemical parameters are shown in Table 6.

TABLE 6 - Effect of CE pre-treatment (500 $\mathrm{mg} \mathrm{kg}^{-1}$ ) on CP-induced oxidative stress ( $75 \mathrm{mg} \mathrm{kg}^{-1}$ ) for the evaluation of blood biochemical parameters.

\begin{tabular}{cccccc}
\hline Treatments & $\begin{array}{c}\mathrm{HCT} \\
(\%)\end{array}$ & $\begin{array}{c}\text { WBC } \\
\left(10^{9} \mathrm{~L}^{-1}\right)\end{array}$ & $\begin{array}{c}\mathrm{RBC} \\
\left(10^{12} \mathrm{~L}^{-1}\right)\end{array}$ & $\begin{array}{c}\mathrm{Hb} \\
\left(\mathrm{g} \mathrm{L}^{-1}\right)\end{array}$ & $\begin{array}{c}\text { Platelets } \\
\left(10^{9} \mathrm{~L}^{-1}\right)\end{array}$ \\
\hline Control & $36.6 \pm 5.2$ & $14.3 \pm 3.0$ & $7.7 \pm 1.2$ & $11.1 \pm 1.9$ & $802.3 \pm 83.1$ \\
$\mathrm{CP}$ & $42.8 \pm 2.3$ & $7.2 \pm 1.2^{\circ}$ & $9.3 \pm 0.6$ & $13.4 \pm 0.8$ & $828.7 \pm 120.7$ \\
$\mathrm{CE}+\mathrm{CP}$ & $43.1 \pm 2.6$ & $6.5 \pm 1.5$ & $9.2 \pm 0.6$ & $13.5 \pm 0.8$ & $641.5 \pm 137.9$ \\
$\mathrm{CE}$ & $42.9 \pm 3.3$ & $11.6 \pm 2.7$ & $9.1 \pm 0.6$ & $13.2 \pm 0.9$ & $868.0 \pm 124.3$ \\
\hline
\end{tabular}

* $\mathrm{p}<0.05$ compared to control. CE (crude extract), CP (cyclophosphamide); Hb, hemoglobin; HCT, hematocrit; RBC, red cell count; WBC, white cell count; $(n=7)$. 


\section{Micronucleus test}

Table 7 shows the frequency of PCEMN, where the group receiving CE plus CP showed a significant reduction of $28 \%(p<0.05)$ micronucleus frequency in relation to the positive control, showing the antimutagenic potential of $\mathrm{CE}$.

TABLE 7 - Effect of CE pre-treatment $(500 \mathrm{mg}$ $\mathrm{kg}^{-1}$ ) on CP-induced oxidative stress $\left(75 \mathrm{mg} \mathrm{kg}^{-1}\right.$ ) to evaluate antimutagenic and mutagenic $\mathrm{CE}$ activity, on PCEMN frequency of bone marrow cells.

\begin{tabular}{|c|c|c|c|}
\hline Treatments & $\begin{array}{c}\text { PCE } \\
\text { observed }\end{array}$ & PCEMN & $\begin{array}{c}\% \\
\text { reduction } \\
\mathrm{MN}\end{array}$ \\
\hline Control & 16.000 & 315 & - \\
\hline $\mathrm{CP}$ & 16.000 & 559 & - \\
\hline $\mathrm{CE}+\mathrm{CP}$ & 16.000 & $491^{\circ}$ & 28 \\
\hline CE & 16.000 & 245 & - \\
\hline
\end{tabular}

" $\mathrm{p}<0.05$ compared to control. CP, cyclophosphamide; $\mathrm{CE}$, crude extract; PCE, polychromatic erythrocytes; PCEMN, micronucleated polychromatic erythrocytes; $(n=8)$.

\section{Histological analysis of the liver}

No significant histological differences were observed between the treated groups, as observed in Figure 4 (A, B, C and D).

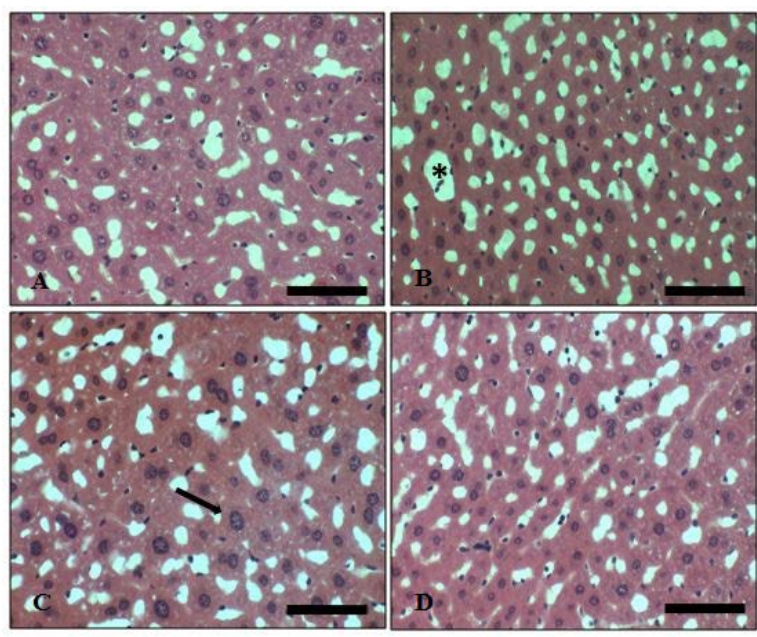

Figure 4 - Photomicrograph of the hepatic tissue of mice Swiss;

$\mathrm{A}=$ control; $\mathrm{B}=\mathrm{CP}\left(75 \mathrm{mg} \mathrm{kg}^{-1}\right) ; \mathrm{C}=\mathrm{CE}+\mathrm{CP} ; \mathrm{D}=\mathrm{CE}(500 \mathrm{mg}$ $\mathrm{kg}^{-1}$ ). Hepatocyte (arrow). Sinusoid (asterisk). Stained HE. Bar $=50 \mu \mathrm{m}$. CE (crude extract), CP (cyclophosphamide).

\section{DISCUSSION}

Plants are sources of remarkable active molecules that can modulate oxidative stress [29]. Currently, this mechanism has been extensively studied. Particularly, the leaves of $C$. papaya have aroused interest for these studies. In the present work, we investigated the effect of the crude extract (CE) of the leaves of $C$. papaya on the induction of oxidative stress using cyclophosphamide (CP) as experimental model adopted.

When performing the phytochemical analysis of CE, flavonoids, quercetin-3 $\beta$-D-glucoside and rutin were identified. The quercetin-3 $\beta-D-$ glucoside was identified from the molecular ion of $463.38(\mathrm{~m} / \mathrm{z}-1)$ and fragment $300.00 \mathrm{~m} / \mathrm{z}-$ 163.38) retention time of 10 minutes and rutin, it presented molecular ion $609.52(\mathrm{~m} / \mathrm{z}-1)$ and fragment $300.20(\mathrm{~m} / \mathrm{z}-309.32)$ retention time 10.3 minutes. The retention time and fragmentation profile of these flavonoids are similar to those of [30] and [31] where the fragmentary ion of the rutin corresponds to the loss of two glycans [32], and the quercetin-3ß-D-glycoside fragment comprises the cleavage of the glycoside group. As regards phytochemical screening, the tests were positive for the presence of alkaloids, saponins and tannins as previously described in the literature by [33] also with aqueous extract.

In biological tests, CP caused a significant reduction $(p<0.05)$ in both SOD and CAT activity of liver tissue.In addition, we observed a decrease in the GSH for all tissues, as described by [34] and [35]. This occurs because during the metabolism of CP ROS is generated that lead to the depletion of antioxidant enzymes in different tissues 13639]. In his studies [37] found that acrolein induces the irreversible inactivation of SOD activity by attacking its amino acid residues, histidine for example, which is pointed out as more susceptible since it is an essential amino acid for SOD activity and for increasing protein carbonylation. Other amino acids are susceptible to attack by acrolein, lysine, cysteine, serine, arginine, and threonine. Acrolein may have its production triggered by various conditions; some are metabolized by cyclophosphamide or oxidation of metal- 
catalyzed polyunsaturated fatty acids. Point to the inactivation process of SOD, the superoxide radical induces the inactivation of the CAT enzyme [38]. The reduction of GSH after CP exposure occurs because GSH conjugates with acrolein to form mercapturic acid making it less likely to exert its toxic effects on the body and facilitates its elimination through the urine [39].

In contrast, CE restored liver CAT activity, helped decrease lipid peroxidation in liver and kidney, increased liver GST and kidney GSH. In a similar study, using papaya epicarp in human cells that had oxidative stress induced by hydrogen peroxide, the extract increased CAT activity and GSH levels, in addition to minimizing lipid peroxidation [40]. In other work [41], rats that had the oxidative stress induced by $\mathrm{Fe}^{2+}$ ions and received aqueous extract of the green fruit, saw a decrease in TBARS. Another study showed that fruit extract was also used against acrylamide-induced oxidative stress, resulting in a decrease in TBARS in the liver and kidney, as well as an increase in GSH and CAT in the tissues mentioned [42]. GST showed a significant increase in its activity, showing that the enzyme was not depleted by $\mathrm{CP}$, similarly to [43]. This may be a response of the body of animals treated to combat the effects of CP. The role of GST is to protect against oxidants by catalyzing the conjugation of the sulfur atom of glutathione to an electrolytic center of toxic xenobiotics in order to produce compounds that facilitate its metabolism and excretion [44]. CE also induced an increase in GST activity, such as has been observed by [45] which identified a similar effect of fruit investigations, found that ethyl acetate extract from the fruits of $C$. papaya on GST increase rat liver cell lines at the $25 \mathrm{mg} \mathrm{mL}^{-1}$ concentration. Considering that the extract of the present study contains rutin and quercetin-3- $\beta$-d-glucoside, we suggest that these flavonoids may be interfering with these findings regarding the various oxidative stress parameters, since there are studies that confirm their antioxidant effects [48-50].

Although CP is widely used in clinical practice, its use produces several side effects in the organism, among them the elevation of liver enzymes [51]. Increased serum levels of AST and ALT are clinical markers used to assess hepatocellular toxicity [52]. CP treatment induced a significant increase of AST and ALP enzymes, as well as increased TBARS in liver and kidney, indicating hepatic and renal damage by $\mathrm{CP}$ administration, results already obtained in the literature [53-55]. This increase in TBARS levels is due to the fact that the production of free radicals mediated by $\mathrm{CP}$ metabolites stimulates the lipid peroxidation process [56].

CE resulted in a significant increase in enzymes ALT and ALP besides TBARS in the livers of the group receiving only the extract, suggesting toxicity. The increase in ALP has already been observed by [57] in Wistar rats using aqueous extract of $C$. papaya leaves for 7 days of administration. This liver toxicity caused by CE may be due to the presence of other substances that may exhibit toxic effects to the body or its prolonged use is not advised. In the phytochemical screening of $\mathrm{CE}$, the tests were positive for the presence of tannins and alkaloids; in low doses these substances have a positive effect, but their excess can lead to hepatotoxicity as already reported by [58]. In addition [59], verified an abundance of calcium oxalate in leaves of $C$. papaya by micromorphology and chemical tests. The presence of these compounds may have led to the toxic event.

Although hepatotoxic action of the extract on hepatic enzymes was observed, no lesions were observed in the hepatocytes or any structure of the liver in the histological analysis of the treated animals. The same was observed by Ismail et al. [60] where rats treated with aqueous extract of leaves C. papaya at a concentration of $140 \mathrm{mg}$ $\mathrm{kg}^{-1}$ for 13 weeks showed no histopathological differences in hepatic tissue. In that study the increase of the ALP enzyme was also observed.

In the histological analysis no damage was observed in the hepatic tissue by CP, although it is common to find works that show that this drug causes liver damage. Observed in mice receiving doses of $25 \mathrm{mg} \mathrm{kg}^{-1}$ for 10 days had dilation of the central and sinusoidal vein, in addition to leukocyte infiltration in histological analysis of the liver [53]. However, cyclophosphamide has been reported as hepatotoxic under unusual conditions, since only 
hepatocellular necrosis is observed at high doses or in conjunction with busulfan or BCNU [61]. In addition, the dose administrated of CP in our work was $75 \mathrm{mg}$ $\mathrm{kg}^{-1}$ for 24 hours, so it is probably that was a short time exposure to cause histological alterations.

A significant increase in the levels of $\mathrm{HCT}, \mathrm{Hb}$, and RBC was observed with decrease of the counts of WBC in the groups CP and CE + CP. The number of WBC from peripheral blood can directly reflect the degree of myelosuppression of chemotherapeutic agents because myelosuppression often first manifests as a decline in white blood cells, followed by a series of hematopoietic impairments [62]. The number of WBC changes most obviously because of its short life cycle [63]. CE also caused a significant increase $(p<0.05)$ in HCT, Hb and RBC levels. Data similar has been observed in the work of Song et al. [64], where treatment with aqueous extract of leaves $C$. papaya during a period of 5 days (twice a day) was administered to a dengue patient, increasing, among other parameters, the $\mathrm{HCT}$ and RBC indexes. In this context, the work of Ahmad et al. [65] demonstrated that the leaf extract of papaya saw healthy increased levels of RBC in mice, indicating strong eritropoietic activation. In the studies of Dharmarathna et al. [66] it has also been observed that the ethanolic extract of the leaves of $C$. papaya promotes an eritropietic stimulation when analyzing cells of the bone marrow of mice. Increases in blood components may be related to the presence of rutin in CE, since it has already been associated with the ability to attenuate myelosuppression and increase eritropoietic production [67]. In addition, the rutin is attributed to the ability to ameliorate ROS action [55].

In the micronucleus test the $\mathrm{CP}$ induced an increase of PCEMN in comparison with control, results already observed in the works done with mouse bone marrow cells using a dose of $50 \mathrm{mg}$ $\mathrm{kg}^{-1}$ [68-70]. The results show that CP induced chromosomal damage, because the drug does not specifically act on tumor cells, binds covalently to DNA and interferes with the cell cycle [71].

The CE showed antimugenic activity, decreasing significantly the PCEMN frequency by $28 \%$, proving this effect. There are no papers in the literature using leaves of $C$. papaya with antimugenic action; on the other hand [72], verified that the aqueous extract of roots of $C$. papaya was antimutagenic in the micronucleus test with bone marrow of Wistar rats. Another study points to antiproliferative and anti-metastatic activity of papaya leaf extract on prostate cancer cell lines [12].The rutin has already been attributed to the ability to repair DNA damage, Wistar rats that were supplemented for two weeks with rutin $(10 \mathrm{mg} / 100 \mathrm{~g})$ prior to induction of carcinogenic damage had reduced damage[73] and in our study rutin is one of the flavonoids present in CE used in the treatment of animals.

\section{CONCLUSION}

The present study showed that the crude extract of leaves of $C$. papaya has benefits against oxidative events, helping to increase antioxidant enzymes, besides inhibiting lipoperoxidation, preventing damage to DNA and showing signs of eritropoietic stimulation. In the phytochemical characterization two flavonoids, quercetin-3 $\beta$-Dglucoside and rutin were found, which we can attribute part of the benefits to this plant. On the other hand, the extract increased ALT and ALP, suggesting toxicity, a fact that may have occurred due to prolonged treatment, causing subchronic intoxication and transient elevation of these enzymes. Therefore, the dose used and in this model of exposure was not considered totally safe. Therefore, the prolonged use of the infusion of papaya leaves is not advisable.

\section{Notes}

This study is the result of part of a dissertation by one of the authors (TCL) called "The use of medicinal plants in the prevention of oxidative stress induced by cyclophosphamide in mice" and it was presented in scientific meeting "VII Simpósio da Amazônia Meridional em Ciências Ambientais, Sinop, Mato Grosso, Brazil, August 8 ${ }^{\text {th }}, 2018$.

\section{Funding}

This study did not receive financial support from external sources 


\section{Conflicts of interest disclosure}

The authors declare no competing interests relevant to the content of this study.

\section{Authors' contributions.}

All the authors declare to have made substantial contributions to the conception, or design, or acquisition, or analysis, or interpretation of data; and drafting the work or revising it critically for important intellectual content; and to approve the version to be published.

\section{Availability of data and responsibility for the results}

All the authors declare to have had full access to the available data and they assume full responsibility for the integrity of these results.

\section{ACKNOWLEDGEMENTS}

The authors express their gratitude to "Coordenação de Aperfeiçoamento de Pessoal de Nivel Superior (CAPES)" and "Fundação de Amparo à Pesquisa do Estado de Mato Grosso (FAPEMAT)" for granting the scholarships. Besides, the authors are grateful to Gabriel Scheffer Sinhorin that reviewed the manuscript.

\section{REFERENCES}

1. Firuzi O, Miri R, Tavakkoli M, Saso L. Antioxidant therapy: Current status and future prospects. Curr Med Chem. 2011:18:3871-88. https://doi. org/10.2174/092986711803414368.

2. Valko M, Leibfritz D, Jan Moncol J, Cronin MTD, M. Mazur M, Telser J. Review: free. radicals and antioxidants in normal physiological functions and human disease. Int J Biochem Cell Biol. 2011;39:44-84. https:// doi.org/10.1016/j.biocel.2006.07.001.

3. Popov D. Protein S-glutathionylation: from current basics to targeted modifications. Arch Physiol Biochem. 2014:12:1-8. https://doi.org/10.3109/13813455.2014.944544.

4. Poprac P, Jomova K, Simunkova M, Kollar V, Rhodes $\mathrm{CJ}$, Valko M. Review: targeting free radicals in oxidative stress-related human diseases. Trends Pharmacol Sci. 2017:38:592-607. https://doi.org/10.1016/.t.tips.2017.04.005..

5. Kallenberg CG. Pro: Cyclophosphamide in lupus nephritis. Nephrol Dial Transplant. 2016;31:1047-52. https://doi.org/10.1093/ndt/gfwo6g
6. Sun Y, Ito S, Nishio N, Tanaka Y, Chen N, Liu L, Isobel $\mathrm{KI}$. Enhancement of the acrolein-induced production of reactive oxygen species and lung injury by Gadd 34. Oxid Med Cell Longev. 2015;2015:170309. https://doi. org/10.1155/2015/170309.

7. Embrapa. Mamão - O produtor pergunta, a Embrapa responde. 500 perguntas 500 respostas. 2nd ed. Brasilia: Embrapa Mandioca e Fruticultura; 2013.

8. Imaga NOA, Gbenle GO, Okochi VI, Akanbi SO, Edeoghon SO, Oibochie, Kehinde V, Bamiro SB. Antisickling property of Carica papaya leaf extract. Afr J Biochem Res. 2009:3(4):102-06.

9. Tan SA, Ramos S, Martín MA, Mateos R, Harvey M, Ramanathan S, Najimudin N, Alam M, Bravo L, Goya $L$. Protective effects of papaya extracts on tert-butyl hydroperoxide mediated oxidative injury to human liver cells (An in-vitro study). Free Rad Antioxid. 2012;2(3):1019. https://doi.org/10.1155/2015/170309.

10. Hasimun P, Suwendar GI, Ernasari. Analgetic Activity of Papaya (Carica papaya L.) leaves extract. Procedia Chem. 2014;13:147-49. https://doi. org/10.1155/2015/170309.

11. Zunjar V, Dash RP, Jivrajani M, Trivedi B, Nivsarkar M. Antithrombocytopenic activity of carpaine and alkaloidal extract of Carica papaya Linn leaves in busulfan induced thrombocytopenic Wistar rats. J Ethnopharmacol. 2016;181:20-25. https://doi.org/10.1016/j.jep.2016.01.035.

12. Pandey S, Walpoleb C, Cabota PJ, Shawa PN, Batrab J. Hewavitharana AK. Selective anti-proliferative activities of Carica papaya leaf juice extracts against prostate cancer. Biomed Pharmacother. 2017:89:515-23. https://doi.org/10.1016/j.biopha.2017.02.050.

13. Indran M, Mahmood AA, Kuppusamy UR. Protective effect of Carica papaya L. leaf extract against alcohol induced acute gastric damage and blood oxidative stress in rats. West Indian Med. 2008:57(4):323-26.

14. Sá PGS, Guimarães AL, Oliveira AP, Siqueira Filho JA, Fontana AP, Damasceno PKF, Branco CRC, Branco A, Almeida JRG. Fenóis totais, flavonoides totais e atividade antioxidante de selaginella convoluta (arn.) spring (Selaginellaceae). Rev. Ciênc Farm Básica Apl. 2012;33:561-66.

15. Sousa CMM, Silva HR, Vieira GM, Ayres MCC, Costa CLS, Araújo DS, Cavalcenti, LCD, Barros EDS, Araújo PBM, Brandão MS, Chaves MH. Fenóis totais e atividade antioxidante de cinco plantas medicinais. Quim Nova. 2007:30(2):35155. https://doi.org/10.1590/S0100-40422007000200021.

16. Castro MS, Pinheiro CCS, Marinho HA. Screeningfitoquímico e físico-químico dos extratos da CurcumazerumbetRoscoe (Zingiberaceae) do Amazonas para a produção de alimentos terapêuticos. Biota Amazônica. 2017;6-11.

17. Duan K, Yuan Z, Guo W, Meng Y, Cui Y, Kong D, Zhang L. LC-MS/MS determination and pharmacokinetic study of five flavone components after solvent extraction/acid hydrolysis in rat plasma after oral administration of Verbena officinalis L. extract. J Ethnopharmacol. 2011;135(2):20108. https://doi.org/10.1016/i.jep.2011.01.002. 
18. Oboh G, Olabiyi AA, Akinyemi AJ. Cyclophosphamide-induced oxidative stress in brain: protective effect of hot short pepper (Capsicum frutescens L. var. abbreviatum). Exp Toxicol Pathol. 2010;62(3):227-33. https:// doi.org/10.1016/j.etp.2009.03.011.

19. Misra HP, Fridovich I. The role of superoxide anion in the auto-oxidation o epinephrine and a simple assay for superoxide dismutase. J Biol Chem. 1972;247(10):3170-75.

20. Nelson DP, Kiesow LA. Enthalphy of decomposition of hydrogen peroxide by catalase at $25^{\circ} \mathrm{C}$ (with molar extinction coefficients of $\mathrm{H}_{2} \mathrm{O}_{2}$ solution in the UV). Anal Biochem. 1972;49(2),474-78. https://doi. org/10.1016/0003-26.97(72) $90451-4$.

21. Habig WH, Pabst MJ, Jacoby WB. Glutathione S-transferase, the first enzymatic step in mercapturic acid formation. J Biol Chem. 1974;249(22):7130-39.

22. Sedlack J, Lindsay RH. Estimation of total, protein-bound, and nonprotein sulfhydryl groups in tissue with Ellman's reagent. Anal Biochem. 1968;25:192-205 https://doi.org/10.1016/0003-2697(68)g0092-4.

23. Buege JA, Aust SD. Microsomal lipid peroxidation methods. Enzymol. 1978;52:302-309. https://doi. org/10.1016/S0076-6879(78)52032-6.

24. Bradford MM. A rapid and sensitive method for the quantification of microgram quantities of protein utilizing the principle of protein-dye binding. Anal Biochem. 1976;72:24854. https://doi.org/10.1016/0003-2697(76)g0527-3.

25. MacGregor JT, Heddle JA, Hit M, Margolin BH, Ramel C. Salamone MF, Tice RR, Wild D. Guidelines for the conduct of micronucleus assays in mammalian bone marrow erythrocytes. Mutat Res 1987:189(12):103-12. https://doi.org/10.1016/0165-1218(87)90016-4.

26. Manoharan K, Banerjee MR. $\beta$-Carotene reduces sister chromatid exchange induce chemical carcinogens in mouse mammary cells in organ culture. Cell Biol. Int. Rep. 1985:9:783-89. https://doi.org/10.1016/03091651(85) $90096-7$.

27. Waters MD, Brady AL, Stack HF, Broxkman HE. Antimutagenic profiles for some model compounds. Mutat Res. 1990;238:57-85. https://doi.org/10.1016/ 0165-1110(90)90039-E.

28. Pereira BCA. Teste estatístico para comparar proporções em problemas de citogenética. In: Rabello-Gay MN, Rodrigues MAR, Monteleone Neto R, organizadores, Mutagênese, carcinogênese e teratogênese: métodos e critérios de avaliação. Soc Bras Gene. 1991;113-21.

29. Kapiszewska M, Soltys E, Visioli F, Cierniak A, Zajac $\mathrm{G}$. The protective ability of the Mediterranean plant extracts against the oxidative DNA damage. The role of the radical oxygen species and the polyphenol content. J Physiol Pharmacol. 2005:56:183-97.

30. Souza M P, Bataglion GA, Silva FM, Almeida RA, Paz WH, Nobre TA, Marinho JV, Salvador MJ, Fidelis CH, Acho LD, Souza AD, Nunomura RC, Eberlin M N, Lima E S, Koolen $\mathrm{HH}$. Phenolic and aroma compositions of pitomba fruit (Talisia esculenta Radlk.) assessed by LC-MS/ MS and HS-SPME/GC-MS. Food Res Int. 2016;83:87-94. https://doi.org/10.1016/i.foodres.2016.01.031.
31. Zhou J, Qi Y, Ritho J, Zhang Y, Zheng X, Wu L, Li Y, Sun L. Flavonoid glycosides as floral origin markers to discriminate of unifloral bee pollen by LC-MS/MS Food Control. 2015:57:54-61. https://doi.org/10.1016/j. foodcont.2015.03.035.

32. Simirgiotis M J, Quispe C, Areche C, Sepúlveda B. Phenolic compounds in Chilean Mistletoe (Quintral, Tristerixtetrandus) analyzed by UHPLC-Q/Orbitrap/MS/MS and its antioxidant properties. Molecules. 2016;21(3):245. https://doi.org/10.3390/molecules21030245.

33. Pandit A, Sachdeva T, Bafna P. Ameliorative effect of leaves of Carica papaya in ethanol and antitubercular drug induced hepatotoxicity. Br J Pharmacol. 2013:3(4):648-661. https://doi.org/10.9734/BJPR/2013/4517.

34. Jnaneshwaria S, Hemshekhara M, Santhosha M S, Sunithaa K, Thusharaa R, Thirunavukkarasub C, Kemparajua K, Girish K S. Crocin, a dietary colorant mitigates cyclophosphamide-induced organ toxicity by modulating antioxidant status and inflammatory cytokines. J Pharm Pharmacol. 2013;65(4):604-14. https://doi.org/10.1111/jphp.12016.

35. Yu Q, Nie SP, Wang JQ, Liu XZ, Yin PF, Huang DF, Li WJ, Gong DM, Xie MY. Chemoprotective effects of Ganoderma atrum polysaccharide in cyclophosphamide-induced mice. Int J Biol Macromol. 2014;64:395-401. https://doi.org/10.1016/j.ijbiomac.2013.12.029.

36. Abraham $P$, Isaac $B$. The effects of oral glutamine on cyclophosphamide-induced nephrotoxicity in rats. Hum Exp Toxicol. 2011;30(7):616-23. https://doi. org/10.1177/0960327110376552.

37. Zarei M, Shivanandappa T. Amelioration of cyclophosphamide-induced hepatotoxicity by the root extract of Decalepishamiltonii in mice. Food Chem Toxicol. 2013:57:179-84. https://doi.org/10.1016/j.fct.2013.03.028.

38. Avci H, Epikmen ET, Ipek E, Tunca R, Birincioglu SS Aksit H, Sekkin S, Akkoç AN, Boyacioglu M. Protective effects of silymarin and curcumin on cyclophosphamide-induced cardiotoxicity. Exp Toxicol Pathol. 2017;69(5):31727. https://doi.org/10.1016/j.etp.2017.02.002.

39. Mansour HH, El kiki SM, Hasan HF. Protective effect of $\mathrm{N}$-acetylcysteine on cyclophosphamide-induced cardiotoxicity in rats. Environ Toxicol Pharmacol. 2015:40(2):41722. https://doi.org/10.1016/j.etap.2015.07.013.

40. Hang JH. Modification and inactivation of Cu,Zn-superoxide dismutase by the lipid peroxidation product acrolein. BMB Rep. 2013;46(11):555-60. https://doi. org/10.5483/BMBRep.2013.46.11.138.

41. Moghe A, Ghare S, Lamoreau B, Mohammad M, Barve S, McClain C, Joshi-Barve S. Molecular mechanisms of acrolein toxicity: Relevance to human disease. Toxicol Sci. 2015:143:242-55. https://doi.org/10.1093/toxsci/kfu233.

42. Guizani N, Waly M, Ali A, Al-Saidi G, Singh V, Bhatt N, Rahman M S. Papaya epicarp extract protects against hydrogen peroxide-induced oxidative stress in human SH-SY5Y neuronal cells. Exp Biol Med. 2011;236(10):120510. https://doi.org/10.1258/ebm.2011.011031. 
43. Oboh G, Olabiyi AA, Akinyemi AJ. Inhibitory effect of aqueous extract of different parts of unripe pawpaw (Carica papaya) fruit on $\mathrm{Fe}^{2+}$ induced oxidative stress in rat pancreas in vitro. Pharm Biol. 2013:51(9):1165-74. https://doi.org/10.3109/13880209.2013.782321.

44. Sadek MK. Antioxidant and immunostimulant effect of Carica papaya Linn aqueous extract in acrylamide intoxicated rats. Acta Infor Med. 2012;20(3):180-185. https://doi.org/10.5455/aim.2012.20.180-185.

45. Fahmy SR, Amien A I, Abd-Elgleel FM, Elaskalany SM. Antihepatotoxic efficacy of Mangifera indica L. polysaccharides against cyclophosphamide in rats. Chem Biol Interact. 2016;244(25):113-20. https://doi.org/10.1016/j.cbi.2015.11.009.

46. Mazzeti AP, Fiorile MC, Primavera A, Lo Bello M. Review: Glutathione transferases and neurodegenerative diseases. Neurochem Int. 2015;82:10-8. https:// doi.org/10.1016/j.neuint.2015.01.008.

47. Nakamura Y, Morimitsu Y, Uzua T, Ohigashi H, Murakami A, Naito Y, Nakagawa Y, Osawa T, Uchida K. A glutathione S-transferase inducer from papaya: rapid screening, identification and structure-activity relationship of isothiocyanates. Cancer Lett. 2000;157(2):193200. https://doi.org/10.1016/S0304-3835(00)00487-0.

48. Huang J, Wang S, Zhu M, Chen J, Zhu X. Effects of Genistein, Apigenin, Quercetin, Rutin and Astilbin on serum uric acid levels and xanthine oxidase activities in normal and hyperuricemic mice. Food Chem Toxicol. 2011:49:1943-47. https://doi.org/10.1016/j.fct.2011.04.029.

49. Shanmugam S, Thangaraj P, Lima BS, Chandran $R$, Souza de Araújo AA, Narain N, Serafini MR, Júnior LJQ. Effects of luteolin and quercetin 3- $\beta$-D-Glucoside identified from Passiflora subpeltata leaves against acetaminophen induced hepatotoxicity in rats. Biomed Pharmacother 2016;83:1278-85. https://doi.org/10.1016/j.biopha.2016.08.044.

50. Caglayan C, Kandemir FM, Darendelioğlu E, Yıldırım S, Kucukler S, Dortbudak MB. Rutin ameliorates mercuric chloride-induced hepatotoxicity in rats viainterfering with oxidative stress, inflammation and apoptosis. J Trace Elements Med Biol. 2019:56:60-8. https://doi. org/10.1016/i.jtemb.2019.07.011.

51. Khan JA, Shahdad S, Makhdoomi MA, Hamid S, Bhat GM, Jan Y, Nazir S, Bashir Z, Banoo S. Effect of cyclophosphamide on the microanatomy of liver of albino rats. Int. J Res Med Sci. 2014:2(4):1466-69. https://doi. org/10.5455/2320-6012.jirms20141141.

52. Gong P, Chen F X, Wang L, Wang J, Jin S, Ma Y M. Protective effects of blueberries (Vaccinium corymbosumL.) extract against cadmium-induced hepatotoxicity in mice. Environ Toxicol Pharmacol. 2014:37(3):1015-27. https://doi.org/10.1016/j.etap.2014.03.017.

53. Basu A, Bhattacharjee, A, Samanta A, Bhattacharya $\mathrm{S}$. Prevention of cyclophosphamide-induced hepatotoxicity and genotoxicity: Effect of an cysteine based oxovanadium (IV) complex on oxidative stress and DNA damage. Environ Toxicol Pharmacol. 2015;40(3):747-57. https://doi.org/10.1016/j.etap.2015.08.035.
54. Bhatt L, Sebastian B, Joshi V. Mangiferin protects rat myocardial tissue against cyclophosphamide induced cardiotoxicity. J. Ayurveda Integr. Med. 2017;8(2):62-67. https://doi.org/10.1016/j.jaim.2017.04.006.

55. Nafees S, Rashid S, Ali N, Hasan SK, Sultana S. Rutin ameliorates cyclophosphamide induced oxidative stress and inflammation in Wistar rats: Role of NFjB/ MAPK pathway. Chem Biol Interact. 2015;231(25):98-107. https://doi.org/10.1016/j.cbi.2015.02.021.

56. Mohamed MR, Emam MA, Hassan NS, Mogadem AI. Umbelliferone and daphnetin ameliorate carbon tetrachloride-induced hepatotoxicity in rats via nuclear factor erythroid 2-related factor 2-mediated heme oxygenase-1 expression. Environ Toxicol Pharmacol. 2014;38(2):531-41. https://doi.org/10.1016/j.etap.2014.08.004.

57. Sheikh N, Younas N, Akhtar T. Effect of Carica papaya leaf formulation on Hematology and Serology of normal rat. Biol Pakistan. 2014;60(1):139-42.

58. Li N, Xia Q, Ruan J, Fu PP, Lin G. Hepatotoxicity and Tumorigenicity Induced by Metabolic. Activation of Pyrrolizidine Alkaloids in Herbs. Current Drug Metabolism. 2011;12(9):823-34. https://doi. org/10.2174/138920011797470119.

59. Zunjar V, Mammen D, Trivedi B M, Daniel M. 2011. Pharmacognostic, Physicochemical and Phytochemical Studies on Carica papaya Linn. Leaves. Pharmacog J. 2011:20(3):5-8. https://doi.org/10.5530/pj.2011.20.2.

6o. Ismail Z, Halim S Z, Abdullah NR, Afzan A, Rashid BAA, Jantan I. Safety Evaluation of Oral Toxicity of Carica papaya Linn. Leaves: A Subchronic Toxicity Study in Sprague Dawley Rats. Evid Based Complement Altern Med. 2014;e741470. https://doi.org/10.1155/2014/741470.

61. Kufe DW, Pollock RD, Weichselbaum RR, Bast RC, Gansler TS, Holland JF, Frei E, editors. Holland-Frei Cancer Medicine. $6^{\text {th }}$ ed. New York: BC Decker; 2003.

62. Molyneux G, Andrews M, Sones W, York M, Barnett A, Quirk E, Yeung W, Turton J. Haemotoxicity of busulphan, doxorubicin, cisplatin and cyclophosphamide in the female BALB/c mouse using a brief regimen of drug administration. Cell Biol Toxicol. 2011;27(1):13-40. https://doi.org/10.1007/s10565-010-9167-1.

63. LiW, Zhao Y, LiX. Effect of Zishenshengxue capsule on myelosuppression in mice induced by Cyclophosphamide. J Trad Chinese Med. 2013:33(2) (2013):233-237. https://doi.org/10.1016/S0254-6272(13)60131-4.

64. Song Y, Zhang C, Wang C, Zhao L, Wang Z, Dai Z, Lin $S$, Kang $H$, Xiaobin M. Ferulic acid against cyclophosphamide-induced heart toxicity in mice by inhibiting NF-KB Pathway. Evid Based Complement Alternat Med. 2016;e1261270. https://doi.org/10.1155/2016/1261270.

65. Ahmad N, Fazal H, Ayaz M, Abbasil BH, Mohammad I, Fazal L. Dengue fever treatment with Carica papaya leaves extracts. Asian Pac J Trop Biomed. 2011;330-33. https://doi.org/10.1016/S2221-1691(11)60055-5.

66. Dharmarathna LC, Wickramasinghe S, Waduge RN, Rajapakse PV, kularatne SA. Does Carica papaya leaf-extract increase the platelet count? An experimental study in a murine model. Asian Pac J Trop Biomed. 2013:3(9):72024. https://doi.org/10.1016/S2221-1691(13)60145-8. 
67. Tham CS, Chakravarthi S, Haleagrahara N, Alwis R. Morphological study of bone marrow to assess the effects of lead acetate on hemapoiesis and aplasia and the ameliorating role of Carica papaya extract. Exp Ther Med. 2013:5(2):648-52. https://doi.org/10.3892/etm.2012.851.

68. Han X, Xue X, Zhao Y, Li Y, Liu W, Zhang J, Fan S. Rutin-enriched extract from Coriandrum sativum $L$. ameliorates ionizing radiation-induced hematopoietic injury. Int J Mol Sci. 2017:18(5):942. https://doi.org/10.3390/ijms18050942.

69. Kour J, Alia MN, Ganaiea HA, Tabassum N. Amelioration of the cyclophosphamide induced genotoxic damage in mice by the ethanolic extract of Equisetum arvense. Toxicol Rep. 2017:4:226-33. https://doi.org/10.1016/j.toxrep.2017.05.001.

70. Lin S, Hao G, Longa M, Laia F, Lia Q, Xionga Y, Tiana Y, Laia D. Oyster (Ostrea plicatulaGmelin) polysaccharides intervention ameliorates cyclophosphamide-Induced genotoxicity and hepatotoxicity in mice via the Nrf2-ARE pathway Shuting. Biomed Pharmacother. 2017:95:106771. https://doi.org/10.1016/j.biopha.2017.08.058.

71. Shruthi S, Vijayalaxmi KK. Antigenotoxic effects of a polyherbal drug septilin against thegenotoxicity of cyclophosphamide in mice. Toxicol Rep. 2016:e563571. https://doi.org/10.1016/i.toxrep.2016.07.001.

72. Gamal-Eldeen AM, Abo-Zeidb MAM, Ahmed EF. Anti-genotoxic effect of the Sargassum dentifolium extracts: Prevention of chromosomal aberrations, micronuclei, and DNA fragmentation. Exp Toxicol Pathol. 2013:65:27-34. https://doi.org/10.1016/j.etp.2011.05.005.

73. Ojo OA, Ojo AB, Awoyinka O, Ajiboye BO, Oyinloye BE, Osukoya OA, Olayide II, Ibitayo A. Aqueous extract of Carica papaya Linn roots potentially attenuates arsenic induced biochemical and genotoxic effects in Wistar rats. J Tradit Complement Med. 2018;8(2):324-34. https://doi.org/10.1016/j.jtcme.2017.08.001.

74. Webster RP, Gawde MD, Bhattacharya RK. Protective effect of rutin, a flavonol glycoside, on the carcinogen induced DNA damage and repair enzymes in rats. Cancer Lett. 1996;109:185-91. https://doi.org/10.1016/ S0304-3835(96)04443-6.

\section{Tatiane Cordeiro Luiz}

MD in Environmental Sciences from the Federal University of Mato Grosso (UFMT, Sinop, MT, Brazil), professor of the state (Sinop, MT, Brazil).

\section{Ana Paula Simões da Cunha}

Master's Degree student in Environmental Sciences postgraduate program at the Federal University of Mato Grosso (UFMT, Sinop, MT, Brazil).
PhD in Cellular and Structural Biology from the State University of Campinas (UNICAMP, Campinas, SP, Brazil), Professor at the Federal University of Mato Grosso (UFMT, Sinop, MT, Brazil).

\section{Marina Mariko Sugui}

PhD in Pathology from São Paulo State University Júlio de Mesquita Filho (UNESP, Botucatu, SP, Brazil), Professor and collaborating professor of the Environmental Sciences post graduate program at the Federal University of Mato Grosso (UFMT, Sinop, MT, Brazil).

\section{Rogério de Campos Bicudo}

PhD in Analytical Chemistry from São Paulo University (USP, São Carlos, SP, Brasil), Analyst A at Embrapa Agrossilvipastoril in the laboratory management area (Embrapa, Sinop, MT, Brasil).

\section{Adilson Paulo Sinhorin}

PhD in Chemistry from the Federal University of Santa Maria (UFSM, Santa Maria, RS, Brazil), Permanent Professor of the Environmental Sciences post graduate program at the Federal University of Mato Grosso (UFMT, Sinop, MT, Brazil).

\section{Valéria Dornelles Gindri Sinhorin}

PhD in Toxicological Biochemistry from the Federal University of Santa Maria (UFSM, Santa Maria, RS, Brazil), Permanent Professor of the Environmental Sciences post graduate program at the Federal University of Mato Grosso (UFMT, Sinop, MT, Brazil).

\section{Mailing address:}

Valéria Dornelles Gindri Sinhorin

Câmpus Universitário de Sinop,

Avenida Alexandre Ferronato 1200, Prédio 3, sala 05

Res. Cidade Jardim 78550-728

Sinop, MT, Brasil. 